\title{
Perilaku Prososial Ditinjau Dari Pengaruh Teman Sebaya Dengan Empati Sebagai Variabel Antara Pada Generasi Z
}

\author{
${ }^{1}$ Chadidjah D. Selomo, ${ }^{2}$ Suryanto, ${ }^{3}$ Dyan Evita Santi \\ Program Studi Magister Psikologi Universitas 17 Agustus 1945 Surabaya, \\ Indonesia
}

Email:1dijah_psi@yahoo.co.id, ${ }^{2}$ suryanto@psikologi.unair.ac.id, 3yyanevita@yahoo.co,id

\section{Tersedia Online di}

http://www.jurnal.unublitar.ac.id/i ndex.php/briliant

\begin{tabular}{l}
\hline Sejarah Artikel \\
\hline Diterima pada 8 Juii 2020 \\
Disetujui pada 12 November 2020 \\
Dipublikasikan pada 30 \\
November 2020 \\
Hal. 646-660 \\
\hline
\end{tabular}

\begin{tabular}{l}
\hline Kata Kunci: \\
\hline Prososial; Pengaruh Teman \\
Sebaya; Empati \\
DOI: \\
\hline http://dx.doi.org/10.28926/briliant. \\
v3i4.510
\end{tabular}

\begin{abstract}
Abstrak: Tujuan penelitian ini untuk mengetahui hubungan antara pengaruh teman sebaya terhadap perilaku prososial, hubungan antara pengaruh teman sebaya terhadap empati, hubungan antara empati terhadap perilaku prososial dan hubungan pengaruh teman sebaya dengan perilaku prososial dengan empati sebagai variabel intervening. Populasi pada penelitian ini adalah siswa siswi SMA Wachid Hasyim 2 Taman Sidoarjo yang berjumlah 120 orang. Pengumpulan data menggunakan skala perilaku prososial dengan koefisien realibilitas 0,864 , skala pengaruh teman sebaya dengan koefisien realibilitas 0,869 dan skala empati dengan koefisien realibilitas 0,905 . Data yang terkumpul telah melalui semua uji asumsi klasik dan kemudian dianalisis dengan teknik regresi linier berganda. Berdasarkan hasil perhitungan diatas diketahui bahwa nilai hubungan langsung sebesar 0,408 dan hubungan tidak langsung sebesar 0,185 yang berarti bahwa nilai hubungan langsung lebih besar dari hubungan tidak langsung. Hasil ini menunjukkan
\end{abstract} bahwa empati dapat dikatakan sebagai variabel yang memediasi sebagian (partial mediation) antara variabel pengaruh teman sebaya dengan perilaku prososial. Besarnya nilai R2 atau R Square sebesar 0,607. Hal ini menunjukkan hubungan pengaruh teman sebaya dengan perilaku prososial dengan empati sebesar 60,7 \% sementara sisanya 39,3\% merupakan kontribusi dari variabel-variabel yang lain.

\section{PENDAHULUAN}

Media sosial bagi kalangan remaja di Indonesia seakan sudah menjadi candu, hampir 24 jam mereka tidak lepas dari smartphone (Zaenal, 2015). Perkembangan tekonologi saat ini tidak dapat dibendung lagi, anak-anak dan remaja yang notabene masih berstatus sebagai siswa telah terampil dalam menggunakan teknologi untuk mengakses informasi. (Savolainen, 2007). Semakin banyaknya pengetahuan (dan inovasi) baru yang sangat mudah diakses, menjadikan lebih penting, dari informasi itu sendiri (Rotherham \& Willingham, 2010). Dalam era seperti inilah generasi $\mathrm{Z}$ dilahirkan dan bertumbuh.

Generasi Z adalah generasi yang lahir pada atau setelah tahun 1990 yang telah terbiasa dengan teknologi internet sejak usia dini (Geck, 2006) yang berbeda dengan generasi sebelumnya. Mereka secara finansial lebih besar, kompetitif, menginginkan kebebasan, bekerja multitasking, berkomunikasi dengan tatap muka, murni generasi digital, dan ingin dilayani (Patel, 2017). 
Untuk mencapai kematangan, peserta didik sebagai generasi $\mathrm{Z}$ tidak terlepas dari pengaruh lingkungan fisik, psikis maupun sosial (Caraka, 2015). Pada pengaruh sosial, generasi $\mathrm{Z}$ juga memunculkan suatu bentuk perilaku yaitu perilaku prososial. Dalam hal ini akan terlihat dari tindakan yang dilakukan atau direncanakan untuk menolong orang lain tanpa mempedulikan motif-motif si penolong (Asih \& Pratiwi, 2010).

Perilaku menolong ini, menurut Baron dan Byrne (2005) adalah perilaku prososial sebagai perilaku menolong yang menguntungkan orang lain tanpa harus menyediakan suatu keuntungan langsung pada orang yang melakukan perilaku tersebut yang bahkan dapat mengakibatkan resiko padanya. Selain itu, perilaku prososial berkisar dari tindakan altruisme yang tidak mementingkan diri sendiri sampai dengan tindakan menolong yang sepenuhya di motivasi oleh kepentingan diri sendiri (Uthomah, 2016).

Menurut Brigham, 1991 (dalam Ermi, 2013), menyebutkan bentuk-bentuk yang terdapat pada perilaku prososial, seperti halnya altruisme yang bersedia menolong orang lain secara sukarela, murah hati yang bersedia dermawan dengan orang lain, persahabatan yang mampu menjalin hubungan dekat dengan orang lain, kerja sama yang selalu bersedia untuk bekerja sama demi tercapainya suatu tujuan, menolong untuk membantu orang lain yang mengalami kesulitan, penyelamatan yang dimana bersedia untuk menyelamatkan orang lain yang membutuhkan, pengorbanan yang dimana bersedia untuk berkorban demi orang lain, dan berbagi yang dimana bersedia untuk berbagi perasaan dengan orang lain dalam suasana duka.

Perilaku prososial dapat terbentuk dari adanya empati, respon simpatik dan kemampuan regulasi emosi. Diantara bentuk perilaku prososial, empati berkaitan langsung dengan perilaku prososial dan empati berperan penting dalam membentuk perilaku prososial. Setiap individu menunjukkan rasa empati yang berbeda-beda dengan adanya regulasi emosi yang mengontrol respon empatik pada orang lain yang membutuhkan bantuan (Gordon, 2013). Menurut Baron dan Byrne (2005) individu yang memiliki empati dapat termotivasi untuk melakukan perilaku tolong menolong.

Sementara itu perilaku prososial pada diri individu dipengaruhi oleh faktor personal yaitu empati dan faktor situasional yaitu dukungan sosial teman sebaya. Lebih lanjut, empati dapat diartikan sebagai perasaan simpati dan perhatian terhadap orang lain, khususnya untuk berbagi pengalaman atau secara tidak langsung merasakan penderitaan orang lain. Hubungan antara empati dengan perilaku prososial dibuktikan oleh Eissenberg sebagaimana dikutip Intan dkk (2018) dinyatakan kontribusi empati terhadap perilaku prososial dari hasil penelitian menunjukkan sebesar $42 \%$ terhadap perilaku prososial.

Empati adalah variabel independen yang paling berkontribusi terhadap perilaku prososial. Hal tersebut menunjukan bahwa empati merupakan salah satu faktor yang ber-kontribusi terhadap perilaku prososial. Apabila empati yang dimiliki seseorang semakin tinggi, maka semakin tinggi pula perilaku prososial yang dimiliki. Begitu juga dengan empati dan perilaku prososial. Intan, Suharso dan Sunawan (2018), juga menjelaskan terkait dengan empati yang merupakan salah satu faktor terbentuknya perilaku prososial juga sejalan dengan penelitian yang dilakukan oleh Ekawati dan Martani (2013) tentang pelatihan "SINERGI" yang didalam penelitiannya mencakup materi tentang empati. Hasil penelitian tersebut 
menunjukan ada perbedaan yang signifikan antara kelompok eksperimen dengan kelompok kontrol yang berarti bahwa apabila empati yang dimiliki oleh seseorang semakin baik, maka perilaku prososialnya juga akan semakin baik pula. Hasil penelitian ini juga didukung dengan apa yang disebutkan oleh Staub, yang menyebutkan bahwa empati merupakan salah satu faktor yang mendasari perilaku prososial.

Menurut Baron dan Byrne (2005) individu yang memiliki empati dapat termotivasi untuk melakukan perilaku tolong menolong. Di periode masa peralihan yaitu masa dari kanak-kanak menuju dewasa seperti remaja SMA, dimana akan mengalami banyak perkembangan yang dapat berguna untuk pembentukan kemampuan sosialnya salah satunya perilaku menolong atau prososial. Kemampuan sosial yang terbentuk dengan baik akan memudahkan remaja untuk dapat diterima dengan baik di dalam lingkungannya. Oleh karena itu, peneliti tertarik untuk menggunakan remaja sebagai subjek penelitian memudahkan remaja untuk dapat diterima dengan baik di dalam lingkungannya. Oleh karena itu, peneliti tertarik untuk menggunakan remaja sebagai subjek penelitian.

Perilaku prososial cenderung dianggap positif secara normatif dan mudah untuk mendapatkan respon positif dari sekitarnya, sehingga tidak mengherankan jika remaja-remaja yang memiliki perilaku prososial tinggi mudah untuk diterima oleh teman sebaya dan mudah menarik hati teman-teman untuk menjadi pusat perhatian, Gest (dalam Rahajeng \& Wigati, 2018).

Sementara itu teman sebaya merupakan lingkup sosial yang sangat bermakna bagi remaja. Sebagian besar waktu remaja dihabiskan bersama dengan teman sebaya, bahkan mengalahkan porsi remaja bersama dengan anggota keluarga. Berkaitan dengan kecenderungan remaja untuk bergerak keluar dari keluarga, maka kecenderungan remaja untuk lebih dekat dengan teman sebayanya dapat dipahami sebagai usaha menciptakan dunia yang bebas dari intervensi orang dewasa, khususnya orang tua. Kelompok teman sebaya merupakan individuindividu yang memiliki kesamaan kelompok usia. Pada umumnya, kelompok teman sebaya remaja merupakan teman-teman disekolahnya, utamanya teman sekelasnya (Rahajeng \& Wigati, 2018). Teman sebaya dapat menyediakan persahabatan dan dukungan sebaik belajar berdasarkan pengalaman dalam bekerjasama dan bermain peran. Menurut Sebanc (dalam Evi \& Kumara, 2016), Dukungan persahabatan secara positif berhubungan dengan perilaku prososial, sedangkan konflik persahabatan secara positif berhubungan dengan tindakan agresif dan penolakan teman sebaya.

Sebagaimana penelitian-penelitian sebelumnya seperti yang dilakukan oleh Wulandari (2015) tentang pengaruh dari teman sebaya terhadap perilaku prososial dibuktikan dengan hasil kontribusi sebesar 9,6\%. Penelitian yang dilakukan oleh Rahajeng dan Wigati (2018), Perilaku prososial diidentifikasikan melalui Peer Assessment Prosocial Behavior yang diadaptasi dari Greener (2000). Sedangkan status teman sebaya diidentifikasi melalui teknik sosiometri. Begitu penelitian yang dilakukan oleh Evi dan Kumara (2016), dengan judul Pengaruh Implementasi Program "Temanku Sahabatku" dalam Meningkatkan Perilaku Prososial Anak Pra Sekolah. Ali dan Nina (2019), dengan judul Pengaruh Teman Sebaya Dan Kepercayaan Diri Terhadap Aktualisasi Diri Mahasiswa. Semua penelitian bisa digambarkan bahwa teman sebaya memiliki peranan utama dalam kehidupan remaja, sebab remaja men-ganggap teman-teman lebih dapat memahami keinginannya, termasuk perilaku prososialnya.

648 BRILIANT: Jurnal Riset dan Konseptual

Volume 5 Nomor 4, November 2020 
Peneliti melihat dari beberapa hasil penelitian sebelumnya, terdapat persamaan yang muncul adalah topik tentang pengaruh teman sebaya, perilaku prososial, empati dan generasi Z. Meskipun demikian dalam penelitian ini berbeda dengan sebelumnya, karena setiap penelitian memiliki titik tekan masing-masing. Pada penelitian ini peneliti lebih memfokuskan pengkajian terkait dengan aspek pengaruh teman sebaya, aspek perilaku prososial dan aspek empati. Teknik pengambilan sampel dalam penelitian ini juga berbeda dengan penelitian lainnya, yaitu menggunakan quota sampling dan teknik analisis data menggunakan analisis regresi linier sederhana dan regresi linier berganda (path analyze). Sdeangkan dalam penelitian ini pengambilan sampel secara nonrandom sampling dan teknik analisis regresi.

Selain itu penelitian ini bertujuan untuk mengetahui hubungan antara pengaruh teman sebaya terhadap perilaku prososial, hubungan antara pengaruh teman sebaya terhadap empati, hubungan antara empati terhadap perilaku empati dan hubungan pengaruh teman sebaya dengan perilaku prososial dengan empati sebagai variabel intervening.

Berdasarkan dari fakta dan fenomena di atas, maka diasumsikan bahwasanya generasi $\mathrm{Z}$ memiliki perilaku prososial dengan empati dan berhubungan dengan pengaruh teman sebaya. Oleh karena itu peneliti berusaha mengkaji ulang, meneliti dan melakukan observasi, bagaimana hubungan antara pengaruh teman sebaya terhadap perilaku prososial dengan empati sebagai variabel intervening pada generasi $\mathrm{Z}$

\section{METODE}

Penelitian kualitatif ini dirancang sebagai penelitian populasi, yang subyek populasinya mengambil sebagian dari keseluruhan populasi (Azwar, 2000). Dalam pengambilan sampel menggunakan pendekatan penelitian dengan dua metode dalam menentukan sampel yang sesuai, yaitu pengambilan sampel berbasis pada probabilitas (pemilihan secara random) atau pengambilan sampel secara nonprobabilitas (pemilihan nonrandom) (Jogiyanto, 2008). Dalam penelitian ini sampel ditentukan secara non-probabilitas (pemilihan nonrandom). Selanjutnya dalam penelitian ini disebut penelitian korelasional yang terdiri dari variabel dependent (y), variabel independent (x) dan variabel intervening (z) oleh karena itu teknik analisa yang digunakan adalah analisa regresi.

Adapun Subyek dalam penelitian ini adalah siswa-siswi SMA Wachid Hasyim 2 Taman, Kabupaten Sidoarjo yang berjumlah 480 siswa/i. Selanjutnya akan dijelaskan mengenai gambaran subyek berdasarkan usia dan jenis kelamin. Gambaran subyek penelitian dapat dilihat pada tabel dibawah ini :

1. Subyek berdasarkan usia

Pengelompokan subyek berdasarkan usia, peneliti mendapatkan subyek dengan usia dari 17 sampai 18 tahun dan dikategorikan sebagai berikut.

Tabel 1

Distribusi Sampel Penelitian Berdasarkan Usia

\begin{tabular}{ccc}
\hline Usia & Jumlah $(\mathbf{N})$ & Persentase $(\boldsymbol{\%})$ \\
& & \\
\hline 17 tahun & 46 & 38 \\
18 tahun & 74 & 62 \\
\hline TOTAL & $\mathbf{1 2 0}$ & $\mathbf{1 0 0}$ \\
\hline
\end{tabular}


Berdasarkan pada data dari 120 subyek penelitian terdapat 46 orang yang berusia 17 tahun dengan persentase $38 \%$ dan 74 orang berusia 18 tahun dengan persentase $62 \%$.

2. Subyek berdasarkan jenis kelamin

Berdasarkan jenis kelamin subyek penelitian dikelompokkan menjadi dua, yaitu laki-laki dan perempuan dengan gambaran penyebaran subyek seperti yang terlihat pada tabel berikut ini.

Tabel 2

Distribusi Sampel Penelitian Berdasarkan Jenis Kelamin

\begin{tabular}{lcc}
\hline & Jumlah (N) & Persentase (\%) \\
\hline Laki-laki & 60 & 50 \\
Perempuan & 60 & 50 \\
Total & 120 & 100 \\
\hline
\end{tabular}

Berdasarkan gambaran diatas, dapat dilihat bahwa jumlah subyek laki-laki sebanyak 60 orang $(50 \%)$ dan subyek perempuan sebanyak 60 orang $(50 \%)$.

Peneliti mengambil 25\% dari banyaknya populasi.Penentuan pengambilan jumlah responden (sampel) dilakukan melalui metode quota sampling. Kuota sampling merupakan teknik penelitian untuk menentukan sampel dari populasi yang mempunyai ciri-ciri tertentu sampai jumlah (kuota) yang diinginkan.

Skala perilaku prososial yang mengadaptasi dari penelitian Erni (2013) sesuai dengan aspek-aspek perilaku prososial dari Brigham (1991) yaitu altruisme, murah hati, persahabatan, kerja sama, menolong, penyelamatan, pengorbanan, berbagi.

Adapun metode yang digunakan dalam pengisian skala adalah pernyataanpernyataan yang diajukan secara tertulis kepada responden dan cara menjawabnya dilakukan dengan memberikan tanda centang $(\sqrt{ })$ pada kolom yang telah disediakan. Kriteria skala dalam penelitian ini merupakan jenis skala likert dimana subjek diminta untuk memilih salah satu dari 4 kategori jawaban yang masing-masing jawaban menunjukan kesesuaian pernyataan yang diberikan dengan keadaan yang dirasakan responden sendiri yaitu, "Sangat Setuju" (SS),"Setuju" (S), "Tidak Setuju" (TS), dan "Sangat Tidak Setuju" (STS). Pada pernyataan favourable, skor 4 diberikan bila subyek menjawab Sangat Setuju (SS), skor 3 diberikan bila subyek menjawab Setuju (S), skor 2 diberikan bila subyek menjawab Tidak Setuju (TS) dan skor 1 bila subyek menjawab Sangat Tidak Setuju (STS). Sebaliknya untuk pernyataan-pernyataan unfavorable skor 1 diberikan bila subyek menjawab Sangat Setuju (SS), skor 2 diberikan bila subyek menjawab Setuju (S), skor 3 diberikan bila subyek menjawab Tidak Setuju (TS) dan skor 4 bila subyek menjawab Sangat Tidak Setuju (STS).Dalam hal ini peneliti melakukan uji coba kembali untuk menguji ke validan item tersebut.

Berdasarkan uji coba skala perilaku prososial, dari 70 aitem yang memiliki daya diskriminasi kurang dari 0,25 berjumlah 30 aitem. Sedangkan yang memiliki daya diskriminasi lebih dari 0,25 berjumlah 41 aitem yang bergerak dari angka $0,252-0,747$ dengan reliabilitas alpha sebesar 0,864. 
Tabel 3. Reliabilitas Statistik Try Out

\begin{tabular}{ccc} 
Skala & $\begin{array}{c}\text { Koefisien } \\
\text { Reliabilitas }\end{array}$ & $\begin{array}{c}\text { Jumlah } \\
\text { Aitem }\end{array}$ \\
\hline Perilaku Prososial & 0,864 & 70 \\
\hline
\end{tabular}

Dari hasil try out yang dilakukan oleh peneliti maka diperoleh hasil nilai koefisien reliabilitas skala perilaku prososial sebesar 0.864 dimana harga tersebut dinyatakan baik atau reliabel yang artinya skala tersebut juga baik atau reliabel digunakan sebagai alat ukur.

Skala pengaruh teman sebaya yang digunakan dalam penelitian ini adalah skala pengaruh teman sebaya yang dibuat oleh peneliti dan telah disahkan oleh dosen pembimbing yang telah sesuai dengan aspek-aspek pengaruh teman sebaya dari Suryanto dkk (2012), yaitu konformitas, kompliens dan kepatuhan. Dalam hal ini peneliti melakukan uji coba untuk menguji ke validan item tersebut.

Adapun metode yang digunakan dalam pengisian skala adalah pernyataanpernyataan yang diajukan secara tertulis kepada responden dan cara menjawabnya dilakukan dengan memberikan tanda centang $(\sqrt{ })$ pada kolom yang telah disediakan. Kriteria skala dalam penelitian ini merupakan jenis skala likert dimana subjek diminta untuk memilih salah satu dari 4 kategori jawaban yang masing-masing jawaban menunjukan kesesuaian pernyataan yang diberikan dengan keadaan yang dirasakan responden sendiri yaitu, "Sangat Setuju" (SS), "Setuju" (S), "Tidak Setuju" (TS), dan "Sangat Tidak Setuju" (STS). Pada pernyataan favourable, skor 4 diberikan bila subyek menjawab Sangat Setuju (SS), skor 3 diberikan bila subyek menjawab Setuju (S), skor 2 diberikan bila subyek menjawab Tidak Setuju (TS) dan skor 1 bila subyek menjawab Sangat Tidak Setuju (STS). Sebaliknya untuk pernyataan-pernyataan unfavorable skor 1 diberikan bila subyek menjawab Sangat Setuju (SS), skor 2 diberikan bila subyek menjawab Setuju (S), skor 3 diberikan bila subyek menjawab Tidak Setuju (TS) dan skor 4 bila subyek menjawab Sangat Tidak Setuju (STS).Dalam hal ini peneliti melakukan uji coba kembali untuk menguji ke validan item tersebut.

Berdasarkan uji coba skala pengaruh teman sebaya dari 51 item terdapat 18 aitem yang nilainya kurang dari 0,25 . Sedangkan aitem skala pengaruh teman sebaya yang nilainya lebih dari 0,25 sebanyak 33 item yang memiliki daya diskriminasi aitem lebih dari 0,25 yang bergerak dari 0,253 - 0,703 dengan reliabilitas alpha sebesar 0,869 .

Tabel 4. Reliabilitas Statistik Try Out

\begin{tabular}{ccc} 
Skala & $\begin{array}{c}\text { Koefisien } \\
\text { Reliabilitas }\end{array}$ & Jumlah Aitem \\
\hline $\begin{array}{c}\text { Pengaruh Teman } \\
\text { Sebaya }\end{array}$ & 0,869 & 51 \\
\hline
\end{tabular}

Dari hasil try out skala pengaruh teman sebaya sebesar 0,869 dimana harga tersebut juga dinyatakan baik atau reliabel. Artinya skala tersebut juga baik atau reliabel digunakan sebagai alat ukur.

Berdasarkan uji coba skala empati dari 41 item terdapat 6 aitem yang memiliki daya diskriminasi kurang dari 0,25. Sedangkan 35 item yang memiliki 
daya diskriminasi aitem lebih dari 0,25 yang bergerak dari angka 0,253 - 0,639 dengan reliabilitas alpha sebesar 0,905 .

Tabel 5. Reliabilitas Statistik Try Out

\begin{tabular}{ccc}
\hline Skala & $\begin{array}{c}\text { Koefisien } \\
\text { Reliabilitas }\end{array}$ & $\begin{array}{c}\text { Jumlah } \\
\text { Aitem }\end{array}$ \\
\hline Empati & 0,905 & 41 \\
\hline
\end{tabular}

Dari hasil try out skala empati menunjukkan harga koefisien reliabilitas sebesar 0,905 yang artinya skala tersebut juga baik atau reliabel digunakan sebagai alat ukur.

Menurut Sugiyono (2008) dalam penelitian kuantitatif, teknik analisis data yang digunakanmenjawab rumusan masalah atau menguji hipotesis yang telah dirumuskan dalam proposal. Karena datanya kuantitatif, maka teknik analisis data menggunakan metode statistik yang sudah tersedia menggunakan analisis regresi linier sederhana dan regresi linier berganda.

Sebagaimana dijelaskan di atas bahwa penelitian adalah penelitian korelasional yang terdiri dari variabel dependent $(y)$, variabel independent $(\mathrm{x})$ dan variabel intervening $(\mathrm{z})$ oleh karena itu teknik analisa yang digunakan adalah analisa regresi. Selanjutnya, adanya variabel intervening dalam penelitian ini maka teknik analisa data menggunakan analisa jalur (path analysis). Setelah terpenuhinya prasyarat normalitas sebaran data variabel dependent (y), linearitas hubungan antar variabel independent $(\mathrm{x})$ dengan variabel dependent $(\mathrm{y})$ yaitu pengaruh teman sebaya dengan perilaku prososial.

Hasil uji normalitas diperoleh nilai signifikansi sebesar 0,963>0,05. Karena nilai signifikansi skala tersebut lebih dari 0,05 maka dapat dikatakan bahwa data tersebut terdistribusi normal dan model ini memenuhi asumsi uji normalitas.

Sedangkan hasil uji liniearitas antara variabel perilaku prososial dengan pengaruh teman sebaya menunjukkan taraf signifikansi sebesar $0.135>0,05$ yang artinya bahwa variabel perilaku prososial dengan pengaruh teman sebaya mempunyai hubungan yang linier. Sedangkan uji linieritas antara perilaku prososial dengan empati menunjukkan taraf signifikansi sebesar $0.837>0.05$ yang artinya juga kedua variabel tersebut sama-sama mempunyai hubungan yang linier.

Berdasarkan hasil uji prasyarat data yang dilakukan melalui uji normalitas, keduanya dinyatakan normal. Demikian juga dengan melalui uji linieritas hubungan antar variabelnya dinyatakan korelasinya linier. Hal ini menunjukkan bahwa kedua variabel tersebut memiliki syarat untuk dianalisis menggunakan teknik regresi linier.

\section{HASIL}

Berdasarkan analisis regresi simultan ditemukan nilai Beta 0,408 dan nilai signifikansi dari kedua variabel pengaruh teman sebaya dan perilaku prososial yaitu 0,000 lebih kecil dari 0,05. Maka hasil ini memberikan kesimpulan bahwa pengaruh teman sebaya dengan perilaku prososial terdapat hubungan yang signifikan. Besarnya nilai R2 atau R Square sebesar 0,167. Hal ini menunjukkan hubungan pengaruh teman sebaya dengan prilaku prososial sebesar 16,7\% sementara sisanya 83,3\% merupakan kontribusi dari variabel-variabel yang lain. Dari perolehan hasil analisis regresi diatas dapat dinyatakan bahwa pengaruh teman sebaya dapat menjadi predictor terbentuknya perilaku prososial. Sementara itu, nilai el dapat

652 BRILIANT: Jurnal Riset dan Konseptual

Volume 5 Nomor 4, November 2020 
dicari dengan rumus e $1=\sqrt{(1-0,167}=0,913$ dengan demikian diperoleh diagram jalur model struktur I sebagai berikut:

\section{Diagram 1}

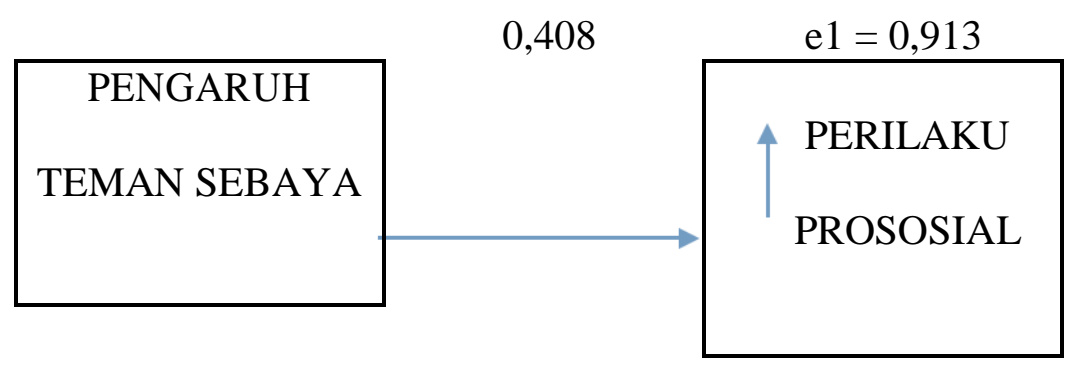

Bahwa ada hubungan antara pengaruh teman sebaya ke empati. Berdasarkan analisis regresi simultan ditemukan nilai Beta 0,307 dan nilai signifikansi dari kedua variabel Pengaruh Teman Sebaya dan Empati 0,000 lebih kecil dari 0,05. Maka hasil ini memberikan kesimpulan bahwa pengaruh teman sebaya dengan empati terdapat hubungan yang signifikan. Besarnya nilai R2 atau R Square sebesar 0,607 . Hal ini menunjukkan hubungan pengaruh teman sebaya dengan empati sebesar $60,7 \%$ sementara sisanya 39,3\% merupakan kontribusi dari variabelvariabel yang lain. Dari perolehan hasil analisis regresi diatas dapat dinyatakan bahwa pengaruh teman sebaya dapat menjadi predictor terbentuknya empati.

Selain itu juga diketahui ada hubunganantara perilaku prososial dengan empati. Berdasarkan analisis regresi simultan ditemukan nilai Beta 0,602 dan nilai signifikansi dari kedua variabel perilaku prososial dan empati yaitu 0,000 lebih kecil dari 0,05. Maka hasil ini memberikan kesimpulan bahwa perilaku prososial dengan empati terdapat hubungan yang signifikan. Besarnya nilai R2 atau R Square sebesar 0, 607. Hal ini menunjukkanhubungan perilaku prososial dengan empati sebesar 60,7 \% sementara sisanya 39,3 \% merupakan kontribusi dari variabelvariabel yang lain. Dari perolehan hasil analisis regresi diatas dapat dinyatakan bahwa perilaku prososial dapat menjadi prediktor terbentuknya empati. Sementara hasil analisis yang lain menunjukkan ada hubungan antara pengaruh teman sebaya dengan perilaku prososial melalui empati. Berdasarkan output analisis regresi sederhana diketahui hubungan langsung yang diberikan pengaruh teman sebaya (x) dengan perilaku prososial (y) dengan nilai beta sebesar 0,408. Sedangkan hubungan tidak langsung pengaruh teman sebaya (x) melalui empati $(\mathrm{z})$ dengan perilaku prososial (y) adalah perkalian antara nilai beta pengaruh teman sebaya (x) dengan empati (z) dan nilai beta perilaku prososial (y) dengan empati (z) yaitu: 0,307 $\mathrm{x}$ $0,602=0,185$. Maka hubungan total yang diberikan pengaruh teman sebaya $(\mathrm{x})$ dengan perilaku prososial (y) adalah hubungan langsung ditambah dengan hubungan tidak langsung yaitu $0,408+0,185=0,593$. Berdasarkan hasil perhitungan diatas diketahui bahwa nilai hubungan langsung sebesar 0,408 dan hubungan tidak langsung sebesar 0,185 yang berarti bahwa nilai hubungan langsung lebih besar dari hubungan tidak langsung. Hasil ini menunjukkan bahwa empati dapat dikatakan sebagai variabel yang memediasi sebagian (partial mediation) antara variabel pengaruh teman sebaya dengan perilaku prososial. Besarnya nilai R2 atau R Square sebesar 0,607. Hal ini menunjukkan hubungan 
pengaruh teman sebaya dengan perilaku prososialdengan empati sebesar 60,7\% sementara sisanya 39,3\% merupakan kontribusi dari variabel-variabel yang lain.

Sementara itu, nilai e2 dapat dicari dengan rumus e2 = $\sqrt{ }(1-0,607=0,627$. Dengan demikian diperoleh diagram jalur model struktur II sebagai berikut:

\section{Diagram 2}

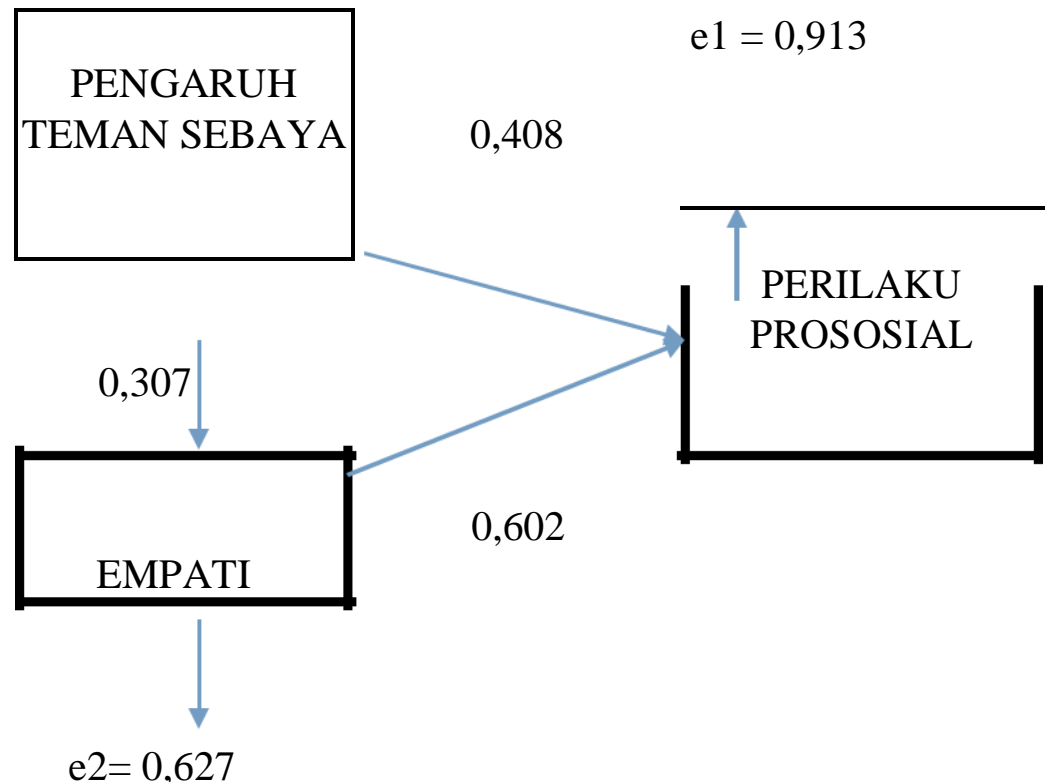

Dari hasil analisis data yang dapat dilihat pada tabel uji regresi linier sederhana, menunjukkan bahwa penelitian yang dilakukan pada 120 siswa-siswi yang termasuk dalam kriteria generasi $\mathrm{Z}$, diperoleh nilai signifikansi variabel pengaruh teman sebaya dengan perilaku prososial sebesar 0.000 dengan taraf kepercayaan $0.05(5 \%)$, atau $0.000<0.05$ dikarenakan signifikasi lebih kecil dari 0.05 , yang berarti terdapat hubungan yang signifikan antara pengaruh teman sebaya dengan perilaku prososialpada generasi Z. Uji Hipotesis Kedua.

Begitu juga analisis data yang dapat dilihat pada tabel uji regresi linier berganda, menunjukkan bahwa penelitian yang dilakukan pada 120 siswa-siswi yang termasuk dalam kriteria generasi $\mathrm{Z}$, diperolehnilai signifikansi variabel pengaruh teman sebaya dengan empati sebesar 0.000 dengan taraf kepercayaan 0.05 (5\%), atau $0.000<0.05$ dikarenakan signifikasi lebih kecil dari 0.05 , yang berarti terdapat hubungan yang signifikan antara pengaruh teman sebaya dan empatipada generasi $\mathrm{Z}$.

Sedangkan dari hasil analisis data yang dapat dilihat pada tabel uji regresi linier berganda, menunjukkan bahwa penelitian yang dilakukan pada 120 siswasiswi yang termasuk dalam kriteria generasi $\mathrm{Z}$, diperolehnilaisignifikansi variabel perilaku prososial dengan empati sebesar 0.000 dengan taraf kepercayaan 0.05 $(5 \%)$, atau $0.000<0.05$. Dikarenakan signifikasi lebih kecil dari 0.05 , yang berarti terdapat hubungan yang signifikan antara perilaku prososial dan empati pada generasi $\mathrm{Z}$. 
Jadi terdapat hubungan antara pengaruh teman sebaya dengan perilaku prososial pada generasi $\mathrm{Z}$ melalui empati. Maksudnya bahwa variabel empati dapat menjadi mediasi antara variabel pengaruh teman sebaya terhadap munculnya perilaku prososial. Empati memiliki peran antara pengaruh teman sebaya terhadap munculnya perilaku prososial..

\section{PEMBAHASAN}

Hubungan pengaruh teman sebaya dengan perilaku prososial dapat diketahui ada hubungan yang signifikan antara pengaruh teman sebaya dengan perilaku prososial pada generasi Z. Hal ini membuktikan semakin tinggi pengaruh teman sebaya, maka juga akan semakin tinggi tingkat perilaku prososial pada generasi Z. Sebagaimana menurut Unita dan Tri (2018) yang menyatakan semakin tinggi kecenderungan perilaku prososial berkaitan dengan semakin tinggi penerimaan lingkungan sekitar, tak terkecuali penerimaan dari teman sebaya.

Pengaruh teman sebaya adalah suatu pergaulan di antara teman sebaya yang dapat mempengaruhi perilaku berupa positif atau negatif. Pengaruh positif tersebut ialah ketika individu bersama teman-teman sebayanya melakukan aktifitas yang bermanfaat seperti membentuk kelompok belajar dan patuh pada norma-norma dalam masyarakat. Sedangkan pengaruh negatif yang dimaksudkan berupa pelanggaran terhadap norma-norma sosial, dan pada lingkungan sekolah berupa pelanggaran terhadap aturan sekolah.

Perilaku prososial cenderung dianggap positif secara normatif dan mudah untuk mendapatkan respon positif dari sekitarnya, sehingga tidak mengherankan jika remaja-remaja yang memiliki perilaku prososial tinggi mudah untuk diterima oleh teman sebaya dan mudah menarik hati teman-teman untuk menjadi pusat perhatian, Gest dkk (dalam Unita \& Tri, 2018).

Teman sebaya merupakan lingkup sosial yang sangat bermakna bagi remaja. Sebagian besar waktu remaja dihabiskan bersama dengan teman sebaya, bahkan mengalahkan porsi remaja bersama dengan anggota keluarga. Berkaitan dengan kecenderungan remaja untuk bergerak keluar dari keluarga, maka kecenderungan remaja untuk lebih dekat dengan teman sebayanya dapat dipahami sebagai usaha menciptakan dunia yang bebas dari intervensi orang dewasa, khususnya orang tua. Kelompok teman sebaya merupakan individu-individu yang memiliki kesamaan kelompok usia. Pada umumnya, kelompok teman sebaya remaja merupakan teman-teman disekolahnya, utamanya teman sekelasnya (Unita \& Tri, 2018).

Sesuai dengan yang disampaikan oleh Myers (dalam Nini, 2016), dimana pertukaran sosial memiliki peran penting bagi remaja, yaitu membahas terkait dengan hubungan timbal balik perilaku sosial antara cinta, pelayanan dan informasi. Keseimbangan dalam pertukaran akan menghasilkan hubungan interpersonal yang memuaskan. Pengalaman akan pertukaran secara timbal balik ini membuat individu lebih percaya bahwa teman sebayanya akan menyediakan bantuan.

Eisenberg \& Mussen (dalam Evi \& Kumara, 2016), membagi perilaku prososial menjadi dua kategori, yaitu perilaku prososial spontan dan perilaku prososial berdasarkan permintaan. Kategori tersebut didasarkan pada motivasi yang mendasari munculnya perilaku prososial. Perilaku prososial spontan berhubungan dengan orientasi anak terhadap orang lain, penjelasan empati untuk keputusan moral, serta tingginya tingkat kemampuan untuk bersosialisasi dengan teman 
sebayanya. Misalnya ketika ada teman sebaya yang menangis, maka anak-anak berusaha menenangkan teman tersebut. Perilaku prososial yang kedua adalah perilaku prososial yang muncul berdasarkan permintaan teman sebaya. Misalnya, ada anak yang kehilangan barang yang sangat dibutuhkan seperti buku dan menanyakan kepada temannya, kemudian temannya mencarikan buku tersebut.

Teman sebaya dapat menyediakan persahabatan dan dukungan sebaik belajar berdasarkan pengalaman dalam bekerjasama dan bermain peran. Menurut Sebanc (dalam Evi \& Kumara, 2016), Dukungan persahabatan secara positif berhubungan dengan perilaku prososial, sedangkan konflik persahabatan secara positif berhubungan dengan tindakan agresif dan penolakan teman sebaya. Hal tersebut juga didukung dengan adanya penelitian yang dilakukan oleh Wulandari (2015) tentang pengaruh dari teman sebaya terhadap perilaku prososial dibuktikan dengan hasil kontribusi sebesar 9,6\% yang semakin menegaskan bahwa teman sebaya memiliki peranan utama dalam kehidupan remaja, sebab remaja menganggap teman-teman lebih dapat memahami keinginannya, tidak terkecuali dengan perilaku prososialnya. Hal tersebut tepat dengan ditunjang adanya aspek pengaruh teman yang memiliki hubungan dengan perilaku prososial pada generasi $\mathrm{Z}$ dalam penelitian ini. Karena konformitas, kompliens dan juga kepatuhan sesuai dengan kebutuhan generasi $Z$ dan dapat dilihat dari hasil penilaian pengerjaan skala tersebut.

Sedangkan hubungan pengaruh teman sebayaa dan empati, dapat diketahui bahwa ada hubungan yang signifikan antara pengaruh teman sebaya dengan empati pada generasi Z. Artinya terbukti bahwa semakin tinggi pengaruh teman sebaya, maka juga akan semakin tinggi tingkat empati pada generasi Z. Myers (dalam Nini, 2016) mengemukakan bahwa empati merupakan hal penting yang mempengaruhi teman sebaya untuk memberikan unsur yang positif, karena empati turut merasakan kesusahan orang lain dengan tujuan mengantisipasi emosi dan memotivasi tingkah laku untuk mengurangi kesusahan dan meningkatkan kesejahteraan orang lain.

Sesuai dengan yang dikemukakan oleh Goleman (1997), bahwasanya dengan sosialisasi, perkembangan kognitif, mood dan feeling, situasi dan tempat memiliki kaitannya dengan hubungan antara pengaruh teman sebaya dengan empati, seperti halnya dengan bersosialisasi maka terciptalah sejumlah emosi yang mengarahkan generasi $\mathrm{Z}$ untuk melihat keadaan teman sebayanya dan turut serta memikirkan tentang teman sebayanya tersebut. Terkait dengan perkembangan kognitifnya, para generasi $\mathrm{Z}$ akan memiliki perkembangan empati dengan perkembangan kognitif yang mengarah kepada kematangan kognitifnya tersebut. Mengenai Mood dan Feelingpada generasi $\mathrm{Z}$ akan mempengaruhi adanya empati kepada lingkungannya, karena situasi perasaan setiap individu ketika berinteraksi dengan teman sebayanya akan mempengaruhi seseorang dalam memberikan respon terhadap perasaan dan perilaku teman sebayanya.

Yang terakhir adalah situasi dan tempat. Dalam penelitian ini seluruh subyek diambil dalam suatu populasi siswa-siswi yang terdapat di Sekolah Menengah Atas Wachid Hasyim 2 Taman, Sidoarjo. Situasi dan tempat ini dapat memberikan pengaruh pada teman sebayanya terhadap proses empati, sehingga pada situasi tertentu siswa-siswi dapat berempati lebih baik dibanding situasi yang lain pada teman sebayanya. Hal tersebut tepat dengan ditunjang adanya aspek pengaruh teman yang memiliki hubungan dengan empati pada generasi $\mathrm{Z}$ dalam penelitian ini. Karena konformitas, kompliens dan juga kepatuhan sesuai dengan

656 BRILIANT: Jurnal Riset dan Konseptual

Volume 5 Nomor 4, November 2020 
kebutuhan generasi $\mathrm{Z}$ dan dapat dilihat dari hasil penilaian pengerjaan skala tersebut.

Adapun hubungan empati dan perilaku prososial juga diketahui ada hubungan yang signifikan antara empati dengan perilaku prososial pada generasi $\mathrm{Z}$. Artinya penelitian ini, membuktikan semakin tinggi empati, maka juga akan semakin tinggi tingkat perilaku prososial pada generasi Z. Menurut Myers (dalam Nini, 2016) bahwa empati juga mempengaruhi seseorang untuk memberikan unsur positif, karena turut merasakan kesusahan orang lain dengan tujuan mengantisipasi emosi dan memotivasi tingkah laku untuk mengurangi kesusahan dan meningkatkan kesejahteraan orang lain. Intan, Suharso dan Sunawan (2018), juga menjelaskan terkait dengan empati yang merupakan salah satu faktor terbentuknya perilaku prososial juga sejalan dengan penelitian yang dilakukan oleh Ekawati dan Martani (2013) tentang pelatihan "SINERGI" yang didalam penelitiannya mencakup materi tentang empati. Hasil penelitian tersebut menunjukan ada perbedaan yang signifikan antara kelompok eksperimen dengan kelompok kontrol, yang berarti bahwa apabila empati yang dimiliki oleh seseorang semakin baik, maka perilaku prososialnya juga akan semakin baik pula. Hasil penelitian tersebut juga didukung dengan apa yang disebutkan oleh Staub, yang menyebutkan bahwa empati merupakan salah satu faktor yang mendasari perilaku prososial.

Sementara itu hubungan pengaruh teman sebaya dengan perilaku prososial melalui empati merupakan lingkup sosial yang sangat bermakna bagi remaja. Sebagian besar waktu remaja dihabiskan bersama dengan teman sebaya, bahkan mengalahkan porsi remaja bersama dengan anggota keluarga. Berkaitan dengan kecenderungan remaja untuk bergerak keluar dari keluarga, maka kecenderungan remaja untuk lebih dekat dengan teman sebayanya dapat dipahami sebagai usaha menciptakan dunia yang bebas dari intervensi orang dewasa, khususnya orang tua. Kelompok teman sebaya merupakan individu-individu yang memiliki kesamaan kelompok usia. Pada umumnya, kelompok teman sebaya remaja merupakan temanteman disekolahnya, utamanya teman sekelasnya (Unita \& Tri, 2018).

Pengaruh teman sebaya adalah suatu pergaulan di antara teman sebaya yang dapat mempengaruhi perilaku berupa positif atau negatif. Pengaruh positif tersebut ialah ketika individu bersama teman-teman sebayanya melakukan aktifitas yang bermanfaat seperti membentuk kelompok belajar dan patuh pada norma-norma dalam masyarakat. Sedangkan pengaruh negatif yang dimaksudkan berupa pelanggaran terhadap norma-norma sosial, dan pada lingkungan sekolah berupa pelanggaran terhadap aturan sekolah.

Perilaku prososial cenderung dianggap positif secara normatif dan mudah untuk mendapatkan respon positif dari sekitarnya, sehingga tidak mengherankan jika remaja-remaja yang memiliki perilaku prososial tinggi mudah untuk diterima oleh teman sebaya dan mudah menarik hati teman-teman untuk menjadi pusat perhatian, Gest dkk (dalam Unita \& Tri, 2018).

Teman sebaya merupakan lingkup sosial yang sangat bermakna bagi remaja. Sebagian besar waktu remaja dihabiskan bersama dengan teman sebaya, bahkan mengalahkan porsi remaja bersama dengan anggota keluarga. Berkaitan dengan kecenderungan remaja untuk bergerak keluar dari keluarga, maka kecenderungan remaja untuk lebih dekat dengan teman sebayanya dapat dipahami sebagai usaha menciptakan dunia yang bebas dari intervensi orang dewasa, khususnya orang tua. Kelompok teman sebaya merupakan individu-individu yang 
memiliki kesamaan kelompok usia. Pada umumnya, kelompok teman sebaya remaja merupakan teman-teman disekolahnya, utamanya teman sekelasnya (Unita \& Tri, 2018).

Sesuai dengan yang disampaikan oleh Myers (dalam Nini, 2016), dimana pertukaran sosial memiliki peran penting bagi remaja, yaitu membahas terkait dengan hubungan timbal balik perilaku sosial antara cinta, pelayanan dan informasi. Keseimbangan dalam pertukaran akan menghasilkan hubungan interpersonal yang memuaskan. Pengalaman akan pertukaran secara timbal balik ini membuat individu lebih percaya bahwa teman sebayanya akan menyediakan bantuan. Eisenberg \& Mussen (dalam Evi \& Kumara, 2016), membagi perilaku prososial menjadi dua kategori, yaitu perilaku prososial spontan dan perilaku prososial berdasarkan permintaan. Kategori tersebut didasarkan pada motivasi yang mendasari munculnya perilaku prososial. Perilaku prososial spontan berhubungan dengan orientasi anak terhadap orang lain, penjelasan empati untuk keputusan moral, serta tingginya tingkat kemampuan untuk bersosialisasi dengan teman sebayanya. Misalnya ketika ada teman sebaya yang menangis, maka anak-anak berusaha menenangkan teman tersebut. Perilaku prososial yang kedua adalah perilaku prososial yang muncul berdasarkan permintaan teman sebaya. Misalnya, ada anak yang kehilangan buku dan menanyakan kepada temannya, kemudian temannya mencarikan buku tersebut.

Teman sebaya dapat menyediakan persahabatan dan dukungan sebaik belajar berdasarkan pengalaman dalam bekerjasama dan bermain peran. Menurut Sebanc (dalam Evi \& Kumara, 2016), Dukungan persahabatan secara positif berhubungan dengan perilaku prososial, sedangkan konflik persahabatan secara positif berhubungan dengan tindakan agresif dan penolakan teman sebaya. Dalam penelitian ini, hubungan pengaruh teman sebaya dengan perilaku prososial juga ada kaitannya dengan empati. Intan, Suharso dan Sunawan (2018), juga menjelaskan terkait dengan empati yang merupakan salah satu faktor terbentuknya perilaku prososial juga sejalan dengan penelitian yang dilakukan oleh Ekawati dan Martani (2013) tentang pelatihan "SINERGI" yang didalam penelitiannya mencakup materi tentang empati. Hasil penelitian tersebut menunjukkan ada perbedaan yang signifikan antara kelompok eksperimen dengan kelompok kontrol, yang berarti bahwa apabila empati yang dimiliki oleh seseorang semakin baik, maka perilaku prososialnya juga akan semakin baik pula. Hasil penelitian tersebut juga didukung dengan apa yang disebutkan oleh Staub, yang menyebutkan bahwa empati merupakan salah satu faktor yang mendasari perilaku prososial.

Empati yang dimiliki oleh setiap individu berbeda-beda, termasuk pada siswa yang sedang dalam masa perkembangan sebagai remaja. Siswa yang mempunyai empati yang tinggi akan mempunyai perilaku prososial yang tinggi pula. Hal tersebut dikarenakan empati itu sendiri merupakan suatu aktivitas untuk memahami dan ikut merasakan apa yang dialami oleh orang lain. Sehingga empati sudah pasti mengarahkan siswa untuk dapat berperilaku prososial, dan mempunyai kontribusi tersendiri pada perilaku prososial. Oleh sebab itu, maka penting untuk menumbuhkan dan selalu menjaga empati yang sudah dimiliki oleh siswa. Selain itu empati juga dapat berubah ubah yang disebabkan oleh berbagai faktor baik dari perkembangan siswa itu sendiri maupun dari lingkungan. Untuk menjaga empati yang dimiliki siswa tetap baik dan dapat meningkat, maka perlu peran dari orangorang di sekitar siswa seperti misalnya guru,orang tua, dan teman sebaya untuk 
menjaga serta mengembangkan empati pada siswa agar semakin baik dan meningkat.

\section{KESIMPULAN}

Berdasarkan hasil penelitian dapat diambil kesimpulan bahwa terdapat hubungan positif yang signifikan antara pengaruh teman sebaya dengan perilaku prososial dan empati sebagai variabel intervening pada generasi Z. Semakin tinggi pengaruh teman sebaya pada generasi $\mathrm{Z}$, maka semakin tinggi pula perilaku prososial dan empatinya. Dan sebaliknya semakin rendah pengaruh teman sebaya pada generasi Z, maka semakin rendah pula perilaku prososial dan empatinya.

\section{SARAN}

Dari sisi praktis bagi generasi $\mathrm{Z}$ diharapkan untuk lebih efektif dalam memilih teman sebaya. Hal ini disebabkan karena teman sebaya memiliki pengaruh yang positif terhadap peningkatan perilaku prososial. Generasi $\mathrm{Z}$ juga dapat menumbuhkan perilaku prososial bersama teman-teman dengan aktif dalam kegiatan sosial seperti penanggulangan kebencanaan. Sementara untuk orang tua atau keluarga generasi $\mathrm{Z}$, hendaknya mendidik anak untuk berperilaku prososial sejak dini dengan cara memberi contoh dalam kehidupan sehari-hari. Dengan pemberian contoh, generasi $\mathrm{Z}$ lebih mudah memahami gambaran bagaimana berperilaku prososial juga dapat mengasah empati anak. Hal ini dapat dilakukan dengan mengikutsertakan anak dalam aktivitas sosial yang disertai pemberian tanggungjawab sehingga rasa sosial anak semakin meningkat. Seperti melatih anak bersedekah saat melihat individu lain mengalami kesulitan, menolong jika terdapat lansia yang membutuhkan bantuan mengangkat tas atau menyebrang jalan. Selain itu, model komunikasi dengan anak mesti dirubah. Frewkensi komunikasi lebih ditingkatkan, dimana orang tua selalu mendekatkan diri dan bersedia mendengarkan anak. Keadaan ini akan menambah kedekatan emosional antara anak dan orang tua. Sehingga komunikasi yang terputus dengan adanya gadget dapat terjalin lagi. Sebab generasi $\mathrm{Z}$ adalah generasi yang aktif dan komunikatif sehingga jika diberikan contoh secara langsung generasi $\mathrm{Z}$ lebih mudah melakukannya

Dari sisi penelitian hendaknya hasil penelitian ini dapat dijadikan sebagai pertimbangan dan landasan untuk mengadakan penelitian lanjutan tentang pengaruh teman sebaya dengan perilaku proosial dan empati sebagai variabel intervening pada generasi Z. Serta berbagai aspek lain yang belum terungkap hendaknya mampu dicari sehingga dapat meningkatkan perilaku prososial pada generasi $\mathrm{Z}$.

\section{DAFTAR RUJUKAN}

Ali, R., Sari, Nina, P. (2019). Pengaruh Teman Sebaya Dan Kepercayaan Diri Terhadap Aktualisasi Diri Mahasiswa. Jurnal Kajian Psikologi Pendidikan dan Bimbingan Konseling. FKIP ULM. Banjarmasin.

Arifin, Z. (2015). Perilaku Remaja Pengguna Gadget. Analisis Teori Sosiologi Pendidikan. Jurnal Tribakti. Jakarta. Vol. 26, No. 2.

Asih,. G. Y,. Pratiwi,. M,. M,. S. (2010). Perilaku Prososial Ditinjau Dari Empati dan Kematangan Emosi. Jurnal Psikologi Universitas Muria. Kudus. Vol. 1 No. 1 
Azwar., S. (2000). Realibilitas dan Validitas. Pustaka Belajar. Yogyakarta.

Baron, R. A. \& Byrne, D. (2005). Psikologi sosial (10th ed.). Erlangga. Jakarta.

Brigham, R. M. (1991). Flexibility in foraging and roosting behaviour by the big brown bat (Eptesicus fuscus). Canadian Journal of Zoology, 69(1), 117-121.

Caraka, P. B., \& Nindiya, E. S. (2015, October). Implementasi Permendikbud RI Nomor 111 Tahun 2014 Dalam Pengembangan Layanan BK di Sekolah Menengah. In Prosiding Seminar Nasional Bimbingan dan Konseling (pp. 55$61)$.

Eisenberg,. N,. Eggum,. N,. D. (2010). Empathy-Related Responding: Associations with Prosocial Behavior, Aggression and Intergroup Relations. Social Issue and Policy Review. Vol. 4, No. 1 pp 143-180

Geck,. C. (2006). The Generation Z : Teaching Information Literacy to The Newest Net Generation. Proquest, Vol. 3, No. 3, PP. 19-23

Goleman, D. (2007). Kecerdasan Emotional (Terjemahan Hermaya T). PT. Gramedia Pustaka Utama. Jakarta

Gordon,. H,. Scarpa,. A,. White,. B. A., \& Dunsmore,. J. C. (2013). Investigating The Relation Between Empathy and Prosocial Behavior ; An Emotion Regulation Framework. Virginia Polytechnic Institute and State University

Ismail, A. G., Zaenal, M. H., \& Shafiai, H. (2015). Philanthrophy in Islam: A promise to Welfare Economics System (No. 1435-3).Jogiyanto,. (2008). Teori Portofolio dan Analisis Investasi. Edisi Kelima. BPPE. Yogyakarta.

Myers., D. G. (2010). Reflections on Religious Belief and Prosociality. Psychological Bulletin, Vol. 138, No. 5.

Myers., D. G. (2012). Psikologi Sosial (Social Psychology) Edisi 10 Buku 2. (Alih Bahasa: Aliya Tusyani, Lala Septiani S, Petty Gina G, Putri Nurdina Sofyan). Salemba Humanika. Jakarta.

Patel,. D. (2017). 8 Ways Generation Z Will Differ From Millenials In The Workplace. Forbes Media 